\title{
Association between polymorphism of ABCG2 gene and somatic cell count in Czech dairy sheep breeds")
}

\author{
MICHALA HOFMANNOVÁ*,**, JANA RYCHTÁŘOVÁ*, ZUZANA SZTANKÓOVÁ*, \\ MICHAL MILERSKI*, LUBOŠ VOSTRÝ*,**, ALENA SVITÁKOVÁ*
}

\author{
*Institute of Animal Science, Prague - Uhříněves, 10400 \\ ${ }^{* *}$ Czech University of Life Sciences, Prague - Suchdol, 16500
}

Hofmannová M., Rychtářová J., Sztankóová Z., Milerski M., Vostrý L., Svitáková A. Association between polymorphism of ABCG2 gene and somatic cell count in Czech dairy sheep breeds

\section{Summary}

In the Czech Republic, dairy sheep have traditionally been used as a dual-purpose species, generating income from both milk and meat. The functionality and health of the mammary gland are directly correlated with milk production, as well as with the hygiene and quality of milk and dairy products. Mastitis is one of the main infectious diseases in dairy sheep. One of the candidate genes that affect milk production traits is the ATP-binding cassette sub-family G member 2 (ABCG2) gene. The ABCG2 gene, a member of the ATP-binding cassette family, transports cytostatic and xenobiotic drugs across the cytoplasmic membrane. The study was based on 1747 records from 387 head of dairy sheep of the Lacaune breed (139) and the East Friesian breed (248). The analysis was performed by means of polymerase chain reactions (PCR). Genomic DNA was extracted from blood. Phenotype data used in the study were provided by the Association of Sheep and Goat Breeders in the Czech Republic (ASGB). We typed all three genotypes: DD, DI and II. In the Lacaune breed, the frequency of occurrence of the major D allele was 0.694 , and the minor I allele had a frequency of occurrence of 0.306 . In contrast, in East Friesian sheep the frequency of allele D was 0.216 and that of allele I was 0.784. Mutation c.683-80_46del in the intron 5 region of the ABCG2 gene confirmed the effect on somatic cell count in the dairy sheep population observed in this study. Further studies are needed to evaluate this possible association in other sheep breed populations. Mutation c.683-80_46del in intron 5 of the ABCG2 gene could be used as a candidate gene for somatic cell count.

Keywords: mammary gland health, mastitis, milk quality

Animal health is a very important issue affecting the profitability of sheep production $(4,9,10,14$, $25)$. Mastitis is becoming a major health problem in dairy sheep (8). It is an inflammatory disease of the mammary gland, which is manifested by an increased number of somatic cells in milk (18). Inflammation of the mammary gland is caused mainly by bacteria - the most prevalent are coagulase-negative staphylococci $(22,24)$. Mastitis has economic implications related to the costs of treatment, premature slaughter (17), reduced growth of lambs and their mortality caused by reduced milk production, and a reduction in the price of milk due to its lower quality (24). Subclinical mastitis negatively influences milk yield, and the low milk yield (especially with a reduced lactose concentration) is associated with a low cheese yield and cheese

1) This study was supported by the National Agency for Agricultural Research of the Czech Republic and the Ministry of Agriculture of the Czech Republic (Prague; Projects no. QJ1510137 and MZE RO0718, resp.). quality (22). The limit of somatic cell count (SCC) is not currently laid down for sheep - in cattle, this limit is $250000-300000 \mathrm{SCC} / \mathrm{ml}$ (18). Leitner et al. (11) classified the quality of milk with respect to reduced milk production in sheep and goats with udder infection: infection of $25 \%$ of udders in a herd was associated with $4.1 \%$ milk loss and $5.2 \%$ curd loss; whereas infection of $75 \%$ of udders in a herd resulted in $12.2 \%$ milk loss and $15.5 \%$ curd loss. The normal level of somatic cells in the milk of non-mastitic sheep is highly variable. It is particularly high in the colostral period and at the end of lactation, but it may be influenced by various factors, such as the age of the animal, its level of production, stress, the sanitary status of the animal, etc. (3). Milk components are also affected by the individual genetic foundation. The so-called candidate genes that influence milk quality should be taken into account when selecting for milk yield. The use of genetic markers in the livestock breeding 
process makes it possible to achieve more effective selection and thus reduce the time required to achieve the breeding aims (12). One of the genetic markers that is linked with such traits is the ATP-binding cassette sub-family $\mathrm{G}$ member 2 ( $A B C G 2$ ) gene.

ATP-binding cassette sub-family $\mathrm{G}$ member 2 $(A B C G 2)$ is located at chromosome $6 \mathrm{NC} 019463.2$ with 21 exons. $A B C G 2$ belongs to the family of transporters, which contains the ATP-binding domain. $A B C G 2$ is responsible for the transport of various cytostatic and xenobiotic drugs across the cell membrane (20). According to Gutiérrez-Gil et al. (7), the $A B C G 2$ gene affects milk yield in sheep and cattle. $A B C G 2$ is also related to the mammary gland phenotypes (milk and mastitis traits) (16). Árnyasi et al. (2) identified a single 35-base insertion/deletion and 13 SNPs, and found a significant association between polymorphisms within $A B C G 2$ and somatic cell count and protein percentage in milk.

The aim of this study was to type the polymorphism at the $A B C G 2$ locus and to determine its association with somatic cell count in Lacaune and East Friesian sheep kept in the Czech Republic.

\section{Material and methods}

In the present study, we used a total of 1747 records from 387 animals from two different sheep populations: Lacaune sheep (139) and East Friesian sheep (248). Phenotype data: milk production and somatic cell count were obtained from a database of the Association of Sheep and Goat Breeders in the Czech Republic (ASGB). Genomic DNA was extracted from blood using a GeneAll ${ }^{\circledR}$ Exgene ${ }^{\mathrm{TM}}$ Blood SV mini kit. The length of the PCR product was 496 bp if the deletion was not present (genotype II) and $461 \mathrm{bp}$ if present (genotype DD). PCR assay was performed in $17 \mu 1$ of reaction mixture containing $10 \mu 1$ PPP Master Mix (Top Bio Ltd., Prague, Czech Republic), $1 \mu$ of template genomic DNA (concentration: $50 \mu \mathrm{g} / \mathrm{ml}$ ), $2 \mu \mathrm{l}$ of forward and reverse primers (concentration: $100 \mathrm{pmol} / \mu \mathrm{l}$ and $4 \mu 1 \mathrm{H}_{2} \mathrm{O}$. We used forward $A B C G 2$ : F 5'-TGCCTCTTCTCCCATATCGT-3' $\left(\mathrm{Tm}(\mathrm{C})=55.0^{\circ} \mathrm{C}\right)$ and reverse $A B C G 2: \mathrm{R} 5^{\prime}$-ACACTCTCAGCCTGCCTCAT-3' $\left(\mathrm{Tm}(\mathrm{C})=58.5^{\circ} \mathrm{C}\right)$ primers $($ Generi Biotech, Hradec Králové, Czech Republic). The PCR primers were designed using the Primer3 software (http://bioinfo. ut.ee/primer3-0.4.0/primer3/). Thermal cycling conditions included an initial denaturation step at $95^{\circ} \mathrm{C}$ for $2 \mathrm{~min}$ followed by 30 cycles of $95^{\circ} \mathrm{C}$ for $30 \mathrm{~s}, 58^{\circ} \mathrm{C}$ for $30 \mathrm{~s}$, and $72^{\circ} \mathrm{C}$ for $50 \mathrm{~s}$, the final extension step at $72^{\circ} \mathrm{C}$ for $5 \mathrm{~min}$ and final cooling to $4^{\circ} \mathrm{C}$ (Biometra Thermoblock: 050-801 TGradient 96, Biometra, Goettingen, Germany). PCR fragments were separated by electrophoresis on a 3\% agarose gel in TBE stained with ethidium bromide using a GeneRuler 50 bp Ladder (Top Bio Ltd., Prague, Czech Republic).

Allele and genotype frequencies and the Hardy-Weinberg equilibrium were determined by SAS version 9.4 (21).

The influence of the polymorphism at the $A B C G 2$ locus on somatic cell count (SCC) and somatic cell score (SCS) obtained by logarithmization of SCC was calculated by the least squares method (LSM) using the SAS v.9.4 software (21). The fixed effects of the herd-year-season of measure- ment (HYS), genotype, age and breed were included in the model. Additionally, the analyses were performed separately for groups of records with low SCC $(\leq 300000)$ and high $\operatorname{SCC}(>300000)$

\section{Results and discussion}

Mastitis is becoming a major health problem in dairy ewes. It is associated with the presence of contaminants in milk (pathogens or antibiotics) and leads to decreased milk production and increased involuntary culling (8). SCC has been described as a good indicator of subclinical infection, although breed-specific thresholds have been advised (1). Selection for mastitis resistance in dairy sheep could be focused mainly on selection against subclinical mastitis based on the somatic cell score (19).

In the present study we typed a genetic polymorphism at position c.683-80 46del in intron 5 of the $A B C G 2$ gene in two different sheep populations: Lacaune sheep and East Friesian sheep kept in the Czech Republic. This mutation is described in the noncoding region and cannot translate to changes in the amino acid sequence. However, it is well known that intron(s) can act as carriers of transcription regulatory elements. They can also be a source of non-coding RNA, and they are involved in alternative splicing, as described by Fedorova and Fedorov (5) and Árnyasi et al. (2).

We found all 3 genotypes: in DD at both alleles there was a 35 bp long deletion, and amplified fragments were $461 \mathrm{bp}$ long; in ID at one allele there was a deletion, and amplified fragments were 461 and 496 bp long; in II no deletion was found, and both alleles were $496 \mathrm{bp}$ long. These results are shown by gel electrophoresis in Figure 1.

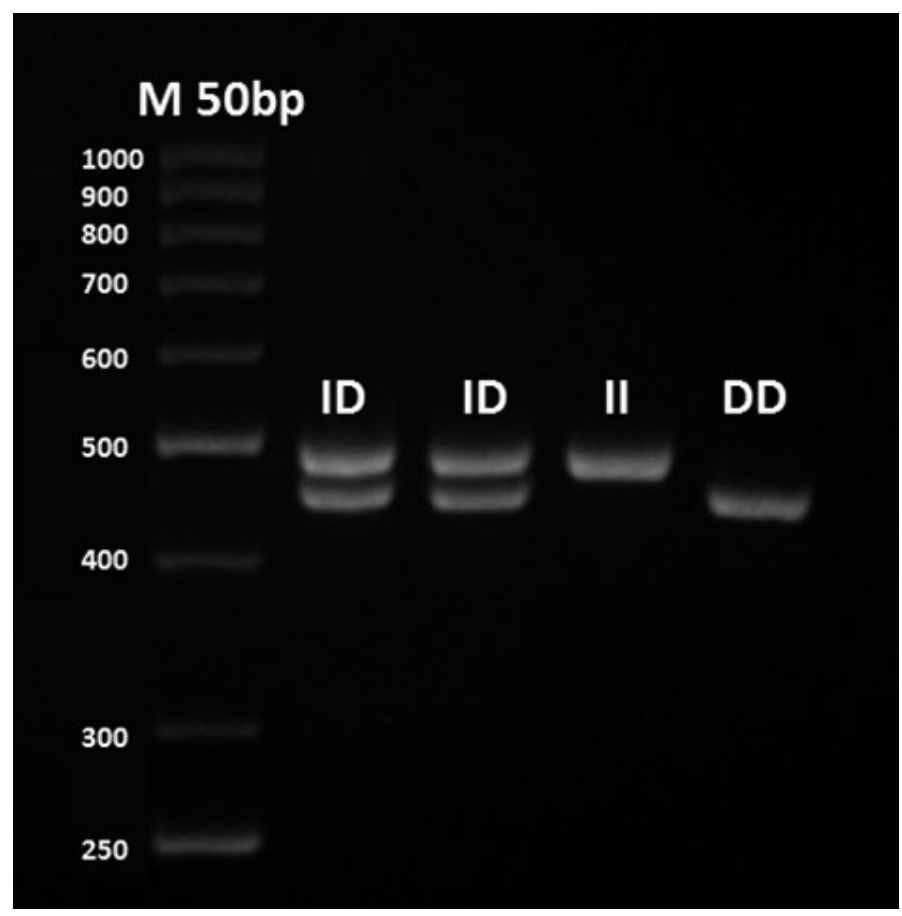

Fig. 1. Polymorphism of c.683-80_46del at $A B C G 2$ in gel electrophoresis 
Tab. 1. Allele and genotype frequencies of the polymorphism in $A B C G 2$ in both sheep breeds

\begin{tabular}{|l|c|c|}
\hline \multicolumn{1}{|c|}{ ABCG2 } & LA $^{1}$ & EF $^{2}$ \\
\hline DD & $72(0.518)$ & $18(0.072)$ \\
ID & $49(0.353)$ & $71(0.286)$ \\
II & $18(0.129)$ & $159(0.641)$ \\
D & 0.694 & 0.216 \\
I & 0.306 & 0.784 \\
$p^{2}$ & 0.482 & 0.047 \\
\hline $2 p q$ & 0.425 & 0.338 \\
\hline$q^{2}$ & 0.093 & 0.615 \\
\hline
\end{tabular}

Explanations: $\mathrm{LA}^{1}$ - Lacaune sheep; $\mathrm{EF}^{2}$ - East Friesian sheep. The figures in brackets are relative frequencies

Tab. 2. Descriptive statistics of somatic cell count in both sheep breeds

\begin{tabular}{|l|c|c|c|c|c|}
\hline \multicolumn{1}{|c|}{ SCC } & $\begin{array}{c}\text { Number } \\
\text { of records }\end{array}$ & $\begin{array}{c}\text { Mean } \\
\text { (thous.) }\end{array}$ & $\begin{array}{c}\text { Std dev. } \\
\text { (thous.) }\end{array}$ & $\begin{array}{c}\text { Minimum } \\
\text { (thous.) }\end{array}$ & $\begin{array}{c}\text { Maximum } \\
\text { (thous.) }\end{array}$ \\
\hline LA $^{1}$ & 696 & 347 & 989 & 6 & 8673 \\
EF $^{2}$ & 1051 & 744 & 1423 & 15 & 9957 \\
\hline
\end{tabular}

Explanations: as in Tab. 1

Table 1 shows the allele and genotype frequency of genetic polymorphism at position c.683-80 46del in intron 5 of the $A B C G 2$ gene in two different sheep populations: Lacaune (LA) and East Friesian sheep (EF).

Allele D (0.694) was the most common allele at the $A B C G 2$ loci opposite to allele I (0.306) in LA. In EF, on the contrary, allele I (0.784) occurred most frequently, opposite to allele D (0.216). A similar result was described in Hungarian sheep populations, especially in Awassi and Gyimesi Racka sheep breeds (2). According to the Hardy-Weinberg equilibrium, both breeds, LA and EF, were in genetic equilibrium (probability $\mathrm{p}<0.01$ ).

In this study, we investigated the association between the genetic polymorphism-genotype combination and SCC (Tab. 2-4). For statistical analysis, we used 384 head of sheep with 1747 records.

Table 2 shows descriptive statistics of somatic cell count in both sheep populations: Lacaune sheep and East Friesian sheep. In the EF population, the value of SCC was evidently higher than in the LA population.

Table 3 presents the least squares means (LSM) for SCC for each genotype in the LA and EF populations. Differences between genotypes were not statistically significant. In LA, however, a positive influence of allele I on somatic cell count can be assumed. The II genotype had the lowest SCC in this case, and the highest value was found for the ID genotype. On the other hand, in EF, in which SCC was much higher, individuals with the II genotype had a higher somatic cell count than animals carrying the DD or ID genotype.

With regard to SCS (Tab. 4), LA sheep with the II genotype showed significantly lower LSM than those with other genotypes, whereas in EF sheep the differences between genotypes were not statistically significant.

EF had a higher frequency of allele I and the II genotype, as well as a much higher somatic cell count than LA. To overcome the large differences in SCC between EF and LA, the analyses were repeated for both breeds within two categories of records: those with low SCC $(\leq 300000)$ and high SCC $(>300000)$. In the low SCC group, the II genotype had the lowest LSM for SCS in both breeds (Tab. 5), while the differences between genotypes in the high SCC group were not statistically significant. To some extent, these results are similar to the findings of Árnyasi et al. (2), who also studied two breeds: Gyimesi Racka with low SCC, where the II genotype was associated with lower SCC, and Awassi with high SCC and no significant differences between genotypes. These results suggest that allele I could be associated with lower basal SCC in the milk of healthy animals, but not with increased resistance to mastitis.

Tab. 3. Somatic cell count (in thousands) for each genotype and both breeds

\begin{tabular}{|l|c|c|c|c|}
\hline \multirow{2}{*}{ Genotype } & \multicolumn{2}{|c|}{ East Friesian } & \multicolumn{2}{c|}{ Lacaune } \\
& LSM & St. err. & LSM & St. err. \\
\hline DD & 739.9 & 170.9 & 294.9 & 67.9 \\
ID & 659.3 & 122.0 & 384.6 & 70.7 \\
II & 825.8 & 107.7 & 139.4 & 123.5 \\
\hline
\end{tabular}

Tab. 4. Somatic cell score for each genotype

\begin{tabular}{|l|c|c|c|c|}
\hline \multirow{2}{*}{ Genotype } & \multicolumn{2}{|c|}{ East Friesian } & \multicolumn{2}{c|}{ Lacaune } \\
& LSM & St. err. & LSM & St. err. \\
\hline DD & 5.67 & 0.16 & $4.57^{\mathrm{a}}$ & 0.09 \\
ID & 5.45 & 0.12 & $4.62^{\mathrm{a}}$ & 0.09 \\
II & 5.63 & 0.10 & $4.18^{\mathrm{b}}$ & 0.16 \\
\hline
\end{tabular}

Explanations: ${ }^{a, b}$ LSM marked with different letters differ significantly $(\mathrm{p}<0.05)$

Tab. 5. Somatic cell score for each genotype in the group of milk samples with $\mathrm{SCC} \leq \mathbf{3 0 0} 000$

\begin{tabular}{|l|c|c|c|c|}
\hline \multirow{2}{*}{ Genotype } & \multicolumn{2}{|c|}{ East Friesian } & \multicolumn{2}{c|}{ Lacaune } \\
& LSM & St. err. & LSM & St. err. \\
\hline DD & $4.85^{\mathrm{a}}$ & 0.10 & $4.16^{\mathrm{a}}$ & 0.05 \\
ID & $4.66^{\mathrm{b}}$ & 0.07 & $4.14^{\mathrm{a}}$ & 0.06 \\
II & $4.60^{\mathrm{b}}$ & 0.07 & $3.92^{\mathrm{b}}$ & 0.11 \\
\hline
\end{tabular}

Explanations: as in Tab. 4.

Tab. 6. Somatic cell score for each genotype in the group of milk samples with SCC $>300000$

\begin{tabular}{|l|c|c|c|c|}
\hline \multirow{2}{*}{ Genotype } & \multicolumn{2}{|c|}{ East Friesian } & \multicolumn{2}{c|}{ Lacaune } \\
& LSM & St. err. & LSM & St. err. \\
\hline DD & 6.75 & 0.19 & 6.72 & 0.13 \\
ID & 6.86 & 0.14 & 6.99 & 0.15 \\
II & 6.96 & 0.12 & 6.56 & 0.31 \\
\hline
\end{tabular}


There have been few reports so far $(2,6,7)$ on the genetic polymorphism of the $A B C G 2$ gene and its effect on milk production traits, especially on SCC in the sheep population. To date, only few reports have explored the effect of $A B C G 2$ on milk production traits in cows $(13,15,16,23)$.

The present study describes genetic variability in c.683-80 46del in intron 5 of the $A B C G 2$ gene and the association of the genotype with SCC in two different sheep populations: Lacaune and East Friesian sheep kept in the Czech Republic. A similar result was reported by Árnyasi et al. (2) in the Hungarian sheep population. Especially Gyimesi Racka and Awassi sheep had a similar allele frequency $(\mathrm{D}=0.62, \mathrm{I}=0.38)$ as Lacaune sheep, but the value of SCC was higher in the Awassi than it was in the Lacaune.

The results regarding the $A B C G 2$ gene in sheep and cattle and its possible effect on milk production (SCC) presented in this study or published elsewhere highlight the need for further investigations of the $A B C G 2$ gene and its chromosomal region. Further studies are needed to evaluate the possible association between $A B C G 2$ and milk production traits as well as SCC in sheep more effectively.

\section{References}

1. Ariznabarreta A., Gonzalo C., San Primitivo F.: Microbiological quality and somatic cell count of ewe milk with special reference to staphylococci. J. Dairy Sci. 2002, 85, 1370-1375.

2.Árnyasi M., Kmlósi I., Kent M. P., Czeglédi L., Gulyás G., Jávor A.: Investigation of polymorphisms and association of the ABCG2 gene with milk production traits in sheep. Livest. Sci. 2013, 154, 64-68.

3. Coulon J. B., Delacroix-Buchet A., Martin B., Pirisi A.: Relationships between animal management and sensory characteristics of cheese: a review. Le Lait 2004, 84, 221-241

4. Dudko P., Junkuszew A., Bojar W., Milerski M., Szczepaniak K., Le Scouarnec J., Schmidová J., Tomczuk K., Grzybek M.: Effect of dietary supplementation with preparation comprising the blend of essential oil from Origanum vulgare (Lamiaceae) and Citrus spp. (Citraceae) on coccidia invasion and lamb growth. Ital. J. Anim. Sci. 2018, 17, 57-65.

5. Fedorova L., Fedorov A.: Introns in gene evolution. Genetica 2003, 118, 112 $-131$.

6. García-Fernández M., Gutiérrez-Gil B., Sánchez J. P., Morán J. A., GarcíaGámez E., Álvarez L., Arranz J. J.: The role of bovine causal genes underlying dairy traits in Spanish Churra sheep. Anim. Genet. 2011, 42, 415-420.

7. Gutiérrez-Gil B., Arranz J. J., Pong-Wong R., García-Gámez E., Kijas J., Wiener P.: Application of selection mapping to identify genomic regions associated with dairy production in sheep. PLoS One. 2014, 9, DOI: 10.1371/ journal.pone.0094623.

8. Gutiérrez-Gil B., El-Zarei M. F., Bayón Y., Álvarez, L., de la Fuente L. F., San Primitivo F., Arranz J. J.: Detection of quantitative trait loci influencing somatic cell score in Spanish Churra sheep. Am. Dairy Sci. Assoc. 2007, 90, 422-426.

9. Junkuszew A., Dudko P., Bojar W., Olech M., Osiński Z., Gruszecki T. M., Greguła Kania M., KuźmakJ., Czerski G.: Risk factors associated with small ruminant lentivirus infection in eastern Poland sheep flocks. Prev. Vet. Med. 2016, 127, 44-49.

10.Junkuszew A., Milerski M., Bojar W., Szczepaniak K., Le Scouarnec J., Tomczuk K., Dudko P., Studzińska M. B., Demkowska-Kutrzepa M., Bracik K.: Effect of various antiparasitic treatments on lamb growth and mortality. Small Rumin. Res. 2015, 123, 305-312.

11. Leitner G., Silanikove N., Merin U.: Estimate of milk and curd yield loss of sheep and goats with intramammary infection and its relation to somatic cell count. Small Rumin. Res. 2008, 74, 221-225.

12. Lende R., Thompson R.: Efficiency of marker assisted selection in the improvement of quantitative traits. Genetics 1990, 124, 743-756.

13. Li C., Sun D., Zhang S., Yang S., Alim A. M., Zhang Q., Li Y., Liu L.: Genetic effects of FASN, PPARGC1A, ABCG2 and IGF1 revealing the association with milk fatty acids in a Chinese Holstein cattle population based on a post genome-wide association study. BMC Genet. 2016, 17:110, DOI: 10.1186/ s12863-016-0418-x

14. Lipecka C., Junkuszew A., Kuźmak J., Gruszecki T. M., Olech M.: Mortality of ewes and their progeny in a flock infected with maedi-visna virus. Bull. Vet. Inst. Pulawy 2011, 55, 361-365.

15. Lopdell T. J., Tiplady K., Struchalin M., Johnson T. J. J., Keehan M., Sherlock R., Couldrey C., Daviss S. R., Snell R. G., Spelman R. J., Littlejohn $M$. D.: DNA and RNA-sequence based GWAS highlights membrane-transport genes as key modulators of milk lactose content. BMC Genomics. 2017, 18 , DOI: $10.1186 / \mathrm{s} 12864-017-4320-3$.

16. Ogorevc J., Kunej T., Razpet A., Dovc P.: Database of cattle candidate genes and genetic markers for milk production and mastitis. Anim. Genet. 2009, 40, $832-851$

17. Persson Y., Nyman A.-K., Söderquist L., Tomic N., Waller K. P.: Intramammary infections and somatic cell counts in meat and pelt producing ewes with clinically healthy udders. Small Rumin. Res. 2017, 156, 66-72.

18. Riggio V., Portolano B.: Genetic selection for reduced somatic cell counts in sheep milk. Small Rumin. Res. 2015, 126, 33-42.

19. Rupp R., Lagriffoul G., Astruc J. M., Barillet F.: Genetic parameters for milk somatic cell score and relationships with production traits in French Lacaune dairy sheep. J. Dairy Sci. 2003, 86, 1476-1481.

20. Sarkadi B., Özvegy-Laczka C., Német K., Váradi A.: ABCG2 - a transporter for all seasons. FEBS Lett. 2004, 567, 116-120.

21. SAS institute Inc. 2013. Base SAS ${ }^{\circledR} 9.4$ procedures guide: Statistical procedures, second edition. Cary, NC: SAS institute Inc.

22. Silanikove N., Merin U., Leitner G.: On effects of subclinical mastitis and stage of lactation on milk quality in goats. Small Rumin. Res. 2014, 122, 76-82.

23. Soltani-Ghombavani M., Ansari-MahyariS., Rostami M., Ghanbari-BaghenoeiS., Edriss M. A.: Effect of polymorphisms in the ABCG2, LEPR and SCD1 genes on milk production traits in Holstein cows. S. Afr. J. Anim. Sci. 2016, 46, 196-203.

24. Spuria L., Biasibetti E., Bisanzio D., Biasato I., De Meneghi D., Nebbia P., Robino P., Bianco P., Lamberti M., Caruso C., Di Blasi A., Peletto S. Masoero L., Dondo A., Capucchio M. T.: Microbial agents in macroscopically healthy mammary gland tissues of small ruminants. PeerJ. 2017, 5, DOI: 10.7717/peerj.3994.

25. Tomczuk K., Grzybek M., Szczepaniak K., Studzińska M., DemkowskaKutrzepa M., Roczén-Karczmarz M., Abdulhammza Abbass Z., Kostro K., Junkuszew A.: Factors affecting prevalence and abundance of A. perfoliata infections in horses from south-eastern Poland. Vet. Parasitol. 2017, 246, $19-24$.

Corresponding author: Ing. Michala Hofmannová, Přátelství 815, 10400 Prague Uhř́něves, Czech Republic; e-mail: hofmannova.michala@vuzv.cz 